\title{
Administrative Rule of Law in Public Participation in Administrative Decision-makings
}

\author{
Guan Baoying and Wang Liqun* \\ (translation from Chinese) \\ Shanghai University of Political Science and Law \\ 7989 Waiqingsong Road, Qingpu District, \\ Shanghai, 201701, China
}

Received 11.12.2017, received in revised form 24.01.2018, accepted 09.02.2018

Public participation in administrative decision-makings has enjoyed a specific legal status in rule of law of developed countries, which usually adjusts the public participation scope and the participation rights via enacting unified administrative procedural laws or special legislations. The new issues faced by China in ruling the country by law and administrative rule of law confronts how its public participation in administrative rule of law will be constructed via administrative system of law. The public participation in administrative decision-makings usually involves three core issues: the first is the scope of administrative decision-makings that the public can participate in; the second is the ways and methods of public participation in administrative decision-makings; the third is the administrative relief of public participation in administrative decision-makings, which requires us to reconstruct it by systems of administrative law accordingly. We believe that it is essential to construct systems such as a category of rights of administrative relative persons, contents of administrative procedures, administrative decision norms and administrative relief.

Keywords: Public Participation, Administrative Decision-makings, System Construction

DOI: 10.17516/1997-1370-0216.

Research area: law.

The Decision of the Central Committee of the Communist Party of China on Several Important Issues Concerning the Comprehensive Advancement of the Rule of Law (hereinafter referred to as the Decision) points out that: 'Public participation, experts' argumentation, risk assessment, legality review and decision by collective discussion shall be defined as major administrative decision legal procedures, so as to make sure that the decision systems are scientific, the procedures are proper, the processes are fair and the responsibilities are clear". This is a programmatic norm and requirement for the legalization and scientifization of administrative decision-makings under the new historical conditions, in which public participation in administrative decision-makings is at a priority among priorities in the construction of the whole decision mechanism. Next a new problem faced by China in governing the country by law

(C) Siberian Federal University. All rights reserved

* Corresponding author E-mail address: Baoyingbanban@sina.com 
and administrative rule of law is how public participation in administrative decision-makings shall be constructed via administrative legal systems in China. However, the author notices that research on this new problem by China's educational circles and practical departments is still lagging behind, which also restricts the adjustment of China's administrative law to public participation in administrative decision-makings ${ }^{1}$. Taking into consideration the abovementioned, the author writes this article to discuss a number of theoretical and practical issues regarding public participation in administrative decisionmakings, and hopes that the educational circles are aroused to lay emphasis on these issues.

\section{Evaluation of public participation in} the administrative decision-makings

In 2004, the State Council formulated an Outline on Comprehensively Promoting the Implementation of Administration according to the Laws, in which corresponding provisions on the standardization of administrative decisionmakings were made. These provisions can be more systematic for public participation in administrative decision-makings by China's administrative law, in which a number of procedures and systems have also been established for public participation in administrative decision-makings ${ }^{2}$, and are the only provisions of legislation on public participation in administrative decision-makings at the central government level in China. It is an indisputable fact that Regulations on Procedures for the Formulation of Administrative Legislation and Regulations on Formulation Procedure of Regulations also stipulate public participation right issues in administrative legislation. However, public participation in administrative legislation and public participation in administrative decision-makings cannot be regarded as issues of the same significance. Some local legislation in China has also established public participation in administrative decisionmakings. For example, "Hunan Provincial Administrative Procedure Regulations" has set up an "Administrative Decision Hearing System", which comparatively systematically stipulated the scope and procedure of public participation in administrative decision-makings ${ }^{3}$. It should be said that public participation in administrative decision-makings in China's current system of the administrative law has already had a certain system in embryonic form, but overall, China's public participation in administrative decisionmakings in the system of the administrative law is still a relatively ambiguous issue. We can make the following evaluation from current public participation in administrative decision-makings.

\section{A. Having breadth but lacking depth}

The breadth and the depth of public participation in administrative decisionmakings are two sides of the same coin. For an administrative decision mechanism with distribution, public participation should be a unity of breadth and depth, neither of which can be neglected. Public participation in administrative decision-makings in China and improvement of administrative law system in China are complementary to each other, part of the administrative law in China is to regulate the government's abstract administrative acts such as "Legislation Law", "Regulations on Record Filling of Rules and Regulations", "Regulations on Making and Record Filling of Shanghai Administrative Normative Documents", etc.; another part is to regulate specific administrative acts, such as "Administrative Licensing Law", "Administrative Penalty Law", "Administrative Enforcement Law" and so on. The administrative codes of the above two categories have established related rights of the administrative relative persons, part of which are exactly 
their rights to participate in administrative decision-makings. In administrative penalty, administrative relative persons' participation in administrative penalty decisions through a hearing process partakes the nature of public participation in administrative decision-makings. For example, some local governments have specially formulated government regulations or government normative documents to adjust administrative decision-makings, which have systematically stipulated the norms and systems of public participation in administrative decisionmakings. From current administrative law norms at central level and local level in China, China's public participation in administrative decisionmakings has already had a certain breadth, just as I mentioned by abstract administrative acts and specific administrative acts involved in a more extensive administrative decision category, which is worthy of recognition, and is an achievement of China's administrative rule of law. At the same time, compared with the breadth of public participation in administrative decisionmakings, its depth is relatively lagging behind. Taking public participation in price-sensitive administrative decision-makings as an example, public participation often cannot curb the rising prices, which lets people produce a universal cognitive that the hearings on prices are often news conferences on price rising, because public participation rights have not been converted from procedural rights into substantive rights during the process ${ }^{4}$, which is an aspect of insufficient public participation. On the other hand, some administrative decision-makings are often accompanied by strong technical colors, and the information on some administrative decisionmakings does not form a symmetric relation between administrative systems and the public. Due to the lack of technical factors in the public and the deficient information possession, their participation in some administrative decision- makings is comparatively superficial. Obviously, participation with breadth but not depth is not what is required by the spirits of a new era of administrative rule of law, which has restricted the governance quality of administrative rule of law in administrative decision-makings.

\section{B. Having formulas but lacking procedures}

In China public participation in administrative decision-makings has already formed a certain tradition and habits, many involved in the operation also have corresponding routines. For example, during the process of decisions related to urban planning the public can be involved in the decision process as interested parties; during the process of decisions related to public interests, the public can also infiltrate the decision process and so on through corresponding media or interest spokesmen. It should be said that China's administrative system has also accumulated some experience in absorbing public participation in administrative decision-makings in the practice of long-term administrative rule of law, while some experience has been fixed and formatted. It is more appropriate to describe the current operation process of public participation as stylization. We say it like this because the current norms for the operational progress of public participation in administrative decisionmakings are either some traditional behavior patterns or some administrative normative documents, the operation process which has been established is only a kind of formula rather than a kind of legal procedure 5 . The reason we can arrive at this kind of conclusion is because China still does not have a legislative administrative procedural code. Neither has it got a legal code enacted by the Supreme Legislature in special adjustment of administrative decision-makings and public participation in administrative decision-makings. In other words, at present 
either routines or operation patterns of China's relevant public participation in administrative decision-makings cannot be classified into the scope of administrative procedures and are not comparable with the concept of legal procedures. Just because of this, the rights of China's public participation in administrative decision-makings cannot obtain stable and orderly guarantee and implementation 6 .

\section{Having scope but lacking categories}

Administrative decision-makings have an extremely critical position in the exercise of administrative authorities. Just because of this, when it comes to administrative authorities and administrative behaviors adjusted by the Administrative Procedural Act of all nations, administrative decision-makings are often the first link and the first essential factor to be adjusted. For example, the Federal Administrative Procedural Act of the United States formulates that: "In order to ensure an effective citizen participation in administrative activities, the law requires administrative organs to publish regulations and related matters in the Federal Register, otherwise administrative organs shall not compel any person in any way to obey any document that should have been published in the Federal Register, nor shall they be adversely affected by such a document, unless they have actually learned the contents of the document in time. At the same time, citizens have rights to request from administrative organs to obtain information and materials stipulated by law, which the administrative organs shall provide unconditionally". Under normal circumstances, an administrative process consists of links such as decision, implementation, consultation, information, supervision and so on, which vertically form an administrative behavior process but horizontally are inseparable from administrative management matters in each field.
That is to say, administrative decision-makings exist in every field of administrative management, which requires that public participation in administrative decision-makings should be a category problem rather than a simple issue of scope. China's current public participation in administrative decision-makings is objective in scope, and does not seem so narrow; the public has an opportunity to participate in decision-makings in almost all areas of administrative management. However, there are no rules or regulations in China's administrative codes and China's administrative systems that explicitly stipulate which specific matters should be participated in in every scope. We believe that it is inevitable that public participation in administrative decisionmakings would have obvious selectivity if there are only participation scopes but no participation categories. At the same time such selectivity makes a considerable part of the public who should participate in administrative decisionmakings lose their opportunities.

\section{Having principles but lacking rules}

Public participation in administrative decision-makings, as one of the problems of administrative rule of law, must be regulated and adjusted by the administrative law under the context of rule by law. It should be said that for a long time the CPC and Chinese government have expectations for the legalization of administrative decision-makings. As early as the 1980s, the National People's Congress put forward the "Principle of Three NOs" in administrative decision-makings, the principles being the following ones: do not make decisions with no more than three plans, do not make decisions without social discussions, and do not make decisions without the experts' argument ${ }^{8}$. This essentially expresses the legal principles of administrative decision-makings in a more scientific way and also confirms that public 
participation in administrative decision-makings is one of the core contents of administrative decision-makings. At present, the provisions of public participation in administrative decision-makings in relevant administrative law documents in China, including some local administrative law documents, often fall into the quagmire of just emphasizing the principles of law, which highlights relevant principles while regulating and controlling public participation in administrative decision-makings, but there is a big gap in the regulation of how these principles work. For example, Provision 2 of Article 34 of Hunan Provincial Administrative Procedure Provisions stipulates that "decision execution organs, supervision organs, citizens, legal persons or other organizations can put forward their objections to the decision-making organ if they believe that major administrative decision-makings and their execution are illegal or inappropriate. It is after serious study when the decision-making organs should decide to continue implementation, cease implementation, temporarily suspend implementation or modify decision-making plans according to the actual condition. The provision clearly underscores public supervision efficiency in administrative decision-makings, but the specific path and procedure by which the public exercises their supervision is not clearly regulated in the subsequent texts. Generally speaking, administrative codes in China do not lack legal principles of public participation in administrative decision-makings, but lack rules that go along with the principles. We know that a complete legal system should be a unity of principles and rules that cannot be separated from each other, and it can even be said that rules seem more important than principles, as specific rights and obligations must be reflected through rules. As Kelsen points out, "legal rights are indeed not interpreted as unconditional interests or wills, but interests protected by law orders, or wills recognized by law orders and brought into force. Laws and rights are brought into some sort of relationship in this way" 9

\section{The path analysis of public participation} in administrative decision-makings

Public participation in administrative decision-makings in the countries where the rule of law is developed has a clear legal status, which often adjusts the categories of public participation and the realization of participation rights through a unified administrative procedural law or special legislation ${ }^{10}$. But administrative decisionmakings generally involve the following core issues:

Thefirstone is the categories of administrative decision-makings that the public can participate in. That is, the kind of administrative decisionmakings the public has the right to participate in and the kind of administrative decision-makings the public does not enjoy the right to participate in. For example, some countries have provisions stating that the public does not enjoy the rights to participate in national defense, diplomacy, the earth structure and geological structure, issues of other high-tech categories, issues involving national secrets, etc. ${ }^{11}$

The second one is the ways and methods of public participation in administrative decisionmakings. That is, by which ways and methods the public can participate in administrative decisionmakings. For example, the public participates in administrative decision-makings via proposal rights, hearings, etc., which is a priority among priorities and the core of adjustment in public participation in administrative decision-makings.

The third one is the administrative relief of public participation in administrative decision-makings. Public participation in administrative decision-makings involves the relationship between administrative subjects and administrative relative persons, the abilities and 
qualifications of public participation constituting the public participation right. If the right is prevented, the public, as the administrative relative person, can apply for legal remedies.

The above three issues on the categories are unavoidable for the public to participate in administrative decision-makings and administrative rule of law, among which the most central issue can be summarized as the paths of participation in administrative decision-makings. These paths are related either with the category, ways and methods or protection of public participation rights.

\section{A. Formal participation and informal} participation

The relationship between the public and the administrative system is very complicated. The administrative system dominates the whole social control process in the countries with administrative rights and functions as their core ${ }^{12}$ in modern times. That is, setting the order for the society, allocating resources and realizing the operation of the social process through administrative power. In social control, the administrative subject seems more important than other state powers, which inevitably forms these kinds of relationships or those kinds of relationships between the administrative system and the public. It is just because of the complexity of these forms of relationships that makes public participation in administrative decision-makings formal in some cases. This implies participation conducted under strict procedural rules. All public participation in the categories adjusted by administrative procedural law belongs to formal participation. Aside from formal participation, the public can also get involved in administrative decision-makings through informal approaches. We know that the public in China can influence the administrative process through more flexible means in some cases. For example, the public can make the administrative subject change their ways of behavior when making administrative decision-makings by giving rationalized proposals to the administrative system. Such rationalized proposals are the result of consultation between the administrative subject and the administrative relative person or influence on the administrative decision-makings during the consultation process. Not long ago, the Central Committee of the Communist Party of China (CPC) issued the Opinions on Strengthening the Construction of Socialist Consultation and Democracy. The Opinion mentions "the issue of solidly advancing governmental consultation", which stipulates the importance of listening to opinions and suggestions from all quarters of the society and assimilating the public, especially the stakeholders, to participate in consultation when involving major issues, major public interests or major livelihood related to economic and social development". This is a new demand from deliberative democracy under new historic conditions. This deliberative democracy must inevitably create a profound impact on the administrative decision-makings. Since the deliberative democracy itself is not an issue of the category of administrative rule of law, it is informal. The public can participate in administrative decision-makings through other informal paths as well. There is some relativity in the concept classification of formal participation and informal participation. However in my opinion, both paths of participation have clear boundaries.

\section{B. Individual participation and universal} participation

The Decision of the Fourth Plenary Session of the Eighteenth Central Committee of the Communist Party of China (the Decision) has made a series of new value propositions for China's social governance while emphasizing 
on rule by law. We know that the governance tradition in China is management-oriented, especially when it comes to government administration. Yet, the Decision has emphasized the importance of social governance. On the one hand, it emphasizes the indispensability of social individuals in the process of governance, while on the other hand it highlights the key role of social organizations in social governance, because social organizations can form a bridge or a bond/ link between the government administrative system and social individuals. Realization of the individuals' rights will seem more rational if done through social organizations, and the relevant rights of the administrative system can also be stripped into social organizations. In modern social governance, governance itself is a multi-operational mechanism. Just as some scholars have pointed out: policies will usually be modified during implementation. Those who participate in the implementation of policies, though working outside the government, also participate in the governance. The governance, namely responsibilities of managing complex societies, involves coordination and cooperation among many public sectors or private sectors and institutions ${ }^{13}$. This valued proposition of the Decisionisalsohelpful for the promotion of the path of public participation in administrative decisionmakings. Thus, we divide the paths of public participation in decision-makings into individual participation and universal participation. In cases of individual participation, participants, as social individuals, can participate in a particular case or an individual issue. Their participation is strongly specific. Universal participation can be regarded as participation in the name of social organizations. For some current administrative decision-makings in China, participation of specific social organizations and specific social groups is often very important ${ }^{14}$. It can be said that their influence on administrative decision- makings is often much greater than that of the individuals of a society. Then in administrative governance how we make a system design for dealing with these two types of participation is also a very important issue.

\section{Private participation and public participation}

Deepening of the market economy makes the diversification tendency of social interests increasingly prominent. Complex social interests have brought new issues for research to social governance and government rule of law. I notice that in recent years, public law academic circles, political academic circles and social academic circles in China have enhanced research on the relationship of interests; people have tried to clarify complex issues such as the connotation of the interests and the relationship between them.

These issues are complex. It should be said that theoretical interpretation and clarification of complex relationships of interests is not an easy task, but the concept of private interests and public interests is relatively certain. For example, the pursuit of self-interest by social individuals can be called private interests, whereas the pursuit of larger interests in a macro-category by society individuals can be called public interests. Administrative decision-makings are often closely connected with these two kinds of interest relationships. That is to say, an administrative decisionmaking is related to either private interests or public interests. Upon further deduction, we can say that participation in administrative decision-makings is considered private participation when individuals are in pursuit of personal interests and public participation when individuals or a certain group of people pursue greater interests. These two kinds of participation paths have different legal values and different legal status. How to clarify the 
two kinds of participation in the construction of the rule of law in administrative decisionmakings is also unavoidable.

\section{Adjudicated participation and}

\section{legislative participation}

In the construction of the administrative hearing system, Administrative Procedure Act of the United States stipulates two types of the administrative hearing. These are adjudicative hearing and decision-making hearing, the system model of which is also different. In my opinion, this classification is instructive for China in improving public participation in administrative decision-makings, according to which we can follow another division in the paths of public participation in administrative decision-makings, that is, adjudicated participation and legislative participation. The former refers to public participation in a small administrative decision-making in an administrative case, that is, the participation in an administrative decision, while the latter refers to the public participation in the administrative legislative behaviors of the government. As pointed out above, administrative decisionmakings and administrative legislation are not concepts with the same meaning. But it is undeniable that any administrative legislative act is bound to be involved in administrative decision-making issues, usually administrative legislation involves a number of administrative decision-makings. During individual hearings and legislative hearings the paths of public participation are vested in two categories, which have qualitative differences. That is why the Administrative Procedure Act of the United States classifies the above two categories. This reminds us that adjudicated participation and legislative participation should be strictly distinguished and follow different principles and rules.
3. The system construction of public participation in administrative decisionmakings

Whether administrative decisions should be subjected to the adjustment of the administrative law has long been a perplexing issue in China. Many scholars believe that administrative decision-makings should not be regulated and constrained by the administrative law, the reason being that administrative decision-makings belong to an issue of the administrative category. That is, it is a matter of the scientific category instead of a matter of the system category. Now that it is a matter of the scientific category, it should not be connected with the administrative law, which seems to be the mainstream cognition in academic circles of public law in China. I have noticed that China's administrative law textbooks rarely do researches on legal adjustment of administrative decision-makings ${ }^{15}$. In fact, several major administrative codes in China such as Local Government Organization Law, Administrative License Law, Administrative Compulsory Law, Administrative Reconsideration Law, etc. do not mention the concept of administrative decisionmakings, let alone legal regulation and control of administrative decision-makings. At present, administrative codes that adjust administrative decision-makings are very few, and are mostly embodied in the departmental administrative law. However, the provisions in administrative decision-makings and new value judgments about public participation in administrative decisionmakings in the Decision clearly distinguish the legal status of administrative decision-makings and the requirements of rule of law for public participation in administrative decision-makings. It should be pointed out that normalization of administrative decision-makings and provisions for public participation in administrative decision-makings, etc. are much more principled, which requires us to restructure it through the 
corresponding system of administrative law. Then how to systematically construct public participation in administrative decision-makings via the management of administrative law? I try to put forward the following new ideas.

\section{A. To construct a system as a category of} the administrative relative persons' rights

The rights of administrative relative persons are said to be the basic issue of administrative rule of law, as the modern administrative law is regarded as the law for controlling conflicts between the administrative subjects and administrative relative persons: "The Administrative law is a controlling regulation for conflicts between the administrative subjects and other social factors, responding and connecting the relationship between administrative subjects and administrative relative persons and other social subjects, which points to the administrative subjects in modern democratic countries"16. In essence, the function of the administrative law is to control the conflicts between administrative subjects and administrative relative persons so that the two are in a harmonious or relatively harmonious relationship, which involves the relationship of the power of the administrative subjects and the rights of administrative relative persons. These two issues are corresponding to each other. Specifically speaking, the deeper and wider the power of the administrative subjects is, the narrower and shallower the rights of administrative relative persons will be. On the contrary, the deeper and wider the rights of administrative relative persons are, the deeper the degree of control in the administrative subjects will be. For example, it is precisely because of this that China's Administrative Punishment Law and Administrative Enforcement Law have established new categories of rights such as the right of defense, the right of refusal, etc. of administrative relative persons which makes the administrative subjects not aggravate the degree of punishment and enforcement as in the past during implementation of administrative punishment and administrative enforcement in the case of administrative relative persons' defense ${ }^{17}$. Thus, the rationalization of administrative rule of law can be seen as inseparable from expansion of the rights of administrative relative persons, which requires us to firstly establish the participation right of the public in the construction of a system of public participation in administrative decision-makings. The system of administrative law should recognize this right of the public and make this right one of the basic rights of administrative relative persons. If this right is not reflected in the system of administrative law, then the construction of other system of public participation in administrative decisionmakings will be more like water without a source. We should deduce this right from the relevant provisions of China's Constitution on the rights of citizens. In fact, there is a clear constitutional basis for the rights of public participation in administrative decisionmakings ${ }^{18}$. How to interpret this constitutional right into the administrative law is what we need to technically deal with in the future.

\section{B. To construct a system as contents of} administrative procedures

Some people reveal the attribute of administrative procedures as "the purpose of administrative procedures is not only to protect the people's rights but also to take the administrative efficiency into account. Therefore, the provisions for administrative procedures in various national laws and regulations have all expressed or implied that administrative procedures should be implemented in a quick way conforming to the purpose as well as saving 
the labour cost ..."19. Therefore, the modern procedural system has a very profound basis for the system of public law. We know that countries with developed rule of law are able to work out their administrative procedural laws because of an important basis of the theory of public law or even a basis of philosophy of right, that is, the generation of the legal idea of "due process" 20 which requires equity, fairness and rules, etc. as a must for the execution of public rights. All in all, administrative decision-makings, as one of the most important public rights, must agree with the due process which demands opportunities and conditions for the public to participate in administrative decision-makings. Basing on this, we believe that when constructing a corresponding system for public participation in administrative decision-makings in China we should have public participation in administrative decision-makings as a fundamental component of China's administrative procedures. We know that sooner or later China will enact a unified code of administrative procedure. During the enactment process of the code, public participation in administrative decision-makings should be taken as one of the issues. To say the least, even if we cannot enact a unified code of administrative procedure in the short term, we can formulate a separate code of administrative procedure to adjust administrative decisionmakings, in which public participation in administrative decision-makings is stipulated. Being the fundamental content of administrative decision-makings, public participation in administrative decision-makings is not only a matter of legislative practice. More importantly, it embodies a much deeper idea of administrative rule of law. Bur if we lack such an idea, it will be difficult to achieve public participation in administrative decision-makings as a rule of law and even harder to obtain adjustment by administrative law norms.

\section{To construct a system for regulation} of administrative decision-makings

Administrative decision-makings should be subject to the adjustment of the Administrative Law. Clear norms and requirements have already been made in the Decision. The legal norms of administrative decision-makings is an institutional system consisting of different systems, in which the public participation system, the expert argumentation system, the risk assessment system, the legitimacy review system, the system of openness in decisionmakings, the post-decision evaluation system, the accountability system of decision-makings, etc. should be included. All these systems together constitute the legal system of administrative decision-makings, though it should be very clear that public participation in administrative decision-makings is only a branch of the decisionmaking system or a specific system. However, it should be pointed out that, first, the legal system in China still lacks a systematic decision-making system and a considerable number of scholars and practitioners are against the idea of constructing a legal system of administrative decision-makings. Second, our cognition of the kind of content included in the system of administrative decisionmakings is also quite unclear. For example, many people will think that administrative decisionmaking errors should be investigated for legal responsibilities, and the relevant administrative leadership and persons in direct responsibility of the errors should undertake legal consequences, etc. through the legal form of administrative accountability ${ }^{21}$. But there is no consensus on public participation in administrative decisionmakings becoming a component of the legal system of administrative decision-makings. Third, we may not necessarily have a clear cognition of what specific content the microsystem of public participation in administrative decision-makings should include. But the above 
three misunderstanding aspects effectively block legal adjustments in administrative decisionmakings. Based on this, I believe that while constructing a system of public participation in administrative decision-makings the issue should be taken as the basic norm of decisionmakings, connecting with other legal systems of administrative decision-makings, while specific systems of public participation in administrative decision-makings should be refined. Only after public participation in administrative decisionmakings is constructed as a decision-making norm can the legal control of administrative decision-makings be effectively implemented. Provisions made by some local normative documents in administrative decision-makings enacted in some places in China on this issue are still relatively rough ${ }^{22}$.

\section{To construct a system as an} administrative relief

We have already clarified above that public participation in administrative decision-makings should be one of their most fundamental rights. Being specific to the administrative law it is one of the basic rights of administrative relative persons. Since it now belongs to the category of the rights of administrative relative persons, it should be incorporated into the relief approaches as other rights. That is, when the rights of administrative relative persons to participate in administrative decision-makings are blocked, there should be follow-up relief systems, or relief via administrative reconsideration, administrative litigation or other litigations, etc. ${ }^{23}$ Since the Administrative Litigation Law of China has abstract administrative acts excluded from the scope of judicial review, it is possible that administrative decision-makings that appear as normative documents or administrative legislation may violate their participation right and as a result the administrative relative persons may lose their opportunities for administrative relief, which is a concrete and realistic problem. What we should treat with caution in future practice of the rule of law is how we can protect public participation in administrative decisionmakings through improved judicial relief. This is due to fact that the lack of administrative relative persons' relief in the right of administrative participation is surely to leave a larger gap for the guarantee of judicial relief. At present, there is still a large loophole in China's related legal systems on the relief blocked by public participation in administrative decision-makings. From the rational analysis of legal mechanism, the right of public participation in administrative decisionmakings should be fully relieved, which is the highest demand of the administrative rule of law in adjusting administrative decision-makings.

\footnotetext{
In the theories of China's administrative law, administrative decision-makings have not been confirmed as formal concepts. Many scholars only regard administrative decision-makings as administrative planning and equate the former with the latter, which has significantly narrowed the scope of administrative decision-makings. Therefore, some of the administrative procedural codes formulated in China do not involve relevant concepts and contents of administrative decisionmakings. This is why in most cases administrative decision-makings operate outside the law in China.

2 Outline on Comprehensively Promoting the Implementation of Administration according to the Laws stipulates that "The administrative decision-making process shall be improved. In addition to what shall be kept confidential according to the laws, items, basis and results of decision-making shall be open to the public and the public shall have the right to consult them. Experts shall be organized in advance to argue the necessity and feasibility of major items of decision-makings regarding national or regional economic and social development as well as strong professional ones. Items of decisionmakings which are widely related to the whole society and closely related to the interests of the people shall be open to the public and widely listen to suggestions via organizing symposiums, hearings, demonstration meetings, etc. Major administrative decision-makings shall have their legitimacy proved during the decision-making process.

3 See Article 131 of the Hunan Provincial Administrative Procedure Provisions.

4 The division of procedural rights and substantive rights is a fundamental legal theoretical issue. Normally, substantive rights can bring substantial benefits to the parties while procedural rights cannot. However, in recent years, procedural rights are more and more valued and even have their independence in value. To the participants, public participation in
} 
administrative decision-makings belongs to the category of procedural rights, which is sure to bring substantial interests to the parties. But public participation in administrative decision-makings as a kind of procedural right has its own independent value.

$5 \quad$ The Provisions on Major Administrative Decision-making Procedures of Yancheng People's Municipal Government (the Provisions) stipulates procedures for administrative decision-makings that will be made by Yancheng People's Municipal Government, including the procedures for public participation in administrative decision-makings. However, the Legislative Law of the People's Republic of China does not confer such cities the power to make governmental regulations. That is to say, The Provisions is only an administrative normative document. As administrative normative documents do not have the same status as the legal code, decision-making procedures set up by the Provisions still do not belong to the category of legal procedures, but is just a form of administrative decision-makings made by Yancheng Municipal People's Government.

${ }^{6}$ Although the public in China has the right to participate in some administrative decision-makings, the current hearing system in China is only a participation system of administrative relative persons. That is to say, their participation does not necessarily directly or indirectly lead to corresponding consequences, because the legal effect of the hearing does not involve the substantive issues in the hearing process, which also shows that the procedural attribute of the hearing system in China is not so strong.

7 Hu Jianmiao, Chief Editor (1997). Review of Foreign Administrative Regulations and Cases. China Legal Publishing House. Edition. P. 27.

8 In the 1980s, comrade Wan Li, the chairman of the Standing Committee of the National People's Congress at the time, proposed the "Principle of Three NOs" in decision-makings.

9 [Austria] Kelsen, Shen Zongling (translator). The General Theory of Law and Country. The Commercial Press. 2013 Edition. P. 131.

10 As countries with developed rule of law have legislated a unified administrative procedural law, their administrative decision-makings and rules of participation are usually centralized in the codes for administrative procedures. China has not formulated a unified administrative procedural law, and current relevant administrative decision-makings in China are still scattered within the departmental administrative law. We have also noted that some countries with developed rule of law have single administrative procedural codes adjusting administrative procedures of administrative decision-makings, in addition to regulations of administrative decision-makings in the unified administrative procedural law. For example, Planning Procedure for Administrative Regulations legislated in the United States in 1985 is a single legislation adjusting administrative decision-makings.

11 In the administrative procedural systems of some developed countries, the administrative decision-makings that are not open to the public participation adopt the writing style of enumerating regulations. In this way, the specific category in which the public can participate in the administrative decision-makings is strictly limited. This is because adopting the writing style of general provisions may lead to the expansion of administrative organs or generalize the scope of the public's inability to participate in administrative decision-makings, which shall be borrowed by the legislative system of China.

12 See [the UK]. Rhodes Hague etc., Zhang Xiaojin etc. (translator) (2007). Comparative Government and Political Introduction. China Renmin University Press. Edition. P. 399.

13 See [the UK] (2007). Rhodes Hague etc., Zhang Xiaojin etc. (translator). Comparative Government and Political Introduction. China Renmin University Press. Edition. P. 7.

14 As a kind of governmental behavior, administrative decision-makings possess the characteristics of futurity, extensivity, uncertainty, etc. Under the multiple market mechanism, some specific groups of people seem to be very crucial for the control of administrative decision-makings, especially in relevant major public decision-makings, specific groups will often control the outcome of decision-makings. In China, this kind of specific groups cannot compare with western interest groups, but they have become a common factor affecting administrative decision-makings in China.

15 Textbooks of Administrative law in China generally can be classified into three categories. The first one is the national universal textbooks compiled by relevant educational or judicial departments. The second one is the normative textbooks compiled and used by some of the colleges and universities themselves. The third one is administrative law textbooks individually compiled by scholars. For now, almost all of the above three categories of textbooks do not mention the legal adjustment issues of administrative decision-makings.

16 Guan Baoying (2013). Administrative Law. Law Press, Edition. First-half volume. P. 99.

17 As we know, before the advent of the Administrative Punishment Law the administrative relative persons did not have the right to defend themselves upon the punishment from the administrative organs. Once they begin to plead against the administrative punishment and put forward reasons for the reversal of the administrative behaviors, the administrative relative persons will be considered to have a bad attitude. Some administrative organs will even impose heavier penalties on the parties. With the publishing of the Administrative Punishment Law, the establishment of the right to plead and relevant rights whereas have changed their previous form of relationship.

18 See Article 27 of The Constitution of the People's Republic of China.

19 Luo Chuanxia (2004). On Administrative Procedural Law. Wu-Nan Book Inc. Edition. P. 58.

20 The Due Process Clause is explicitly stipulated in the Fifth Amendment and the Fourteenth Amendment of the Constitution of the United States of America, which laid down the foundation for the procedural system of modern public law. See Zhu Zengwen (translator) (2014). The Constitution of the United States and its Amendments, In The Commercial Press, 33-34.

${ }_{21}$ The Decision stipulates: "The lifelong accountability system for major decision-makings and its reserved investigation mechanism shall be established. For those critical mistakes in decision-makings or decisions that should be timely made 
in accordance with the law but are dragged on and have caused significant losses and baneful influence, the chief executives, other leaders in charge and related responsible personnel shall be strictly investigated". The Decision significantly strengthens the accountability intensity of administrative decision-makings, which should be reflected by the subsequent administrative legislation of China.

22 Taking Provisions on Major Administrative Decision-Making Procedures of Yancheng People's Municipal Government, stipulated by Yancheng City, as an example, the provisions on public participation in administrative decision-makings are not specific enough, especially without regulations from the perspective of public participation right, from which we cannot clearly see how the public is relieved when this right cannot be achieved.

23 It ought to be said that when public participation in administrative decision-makings is blocked, the relevant relief path is still relatively broad. For example, the public can achieve corresponding right of relief by appealing to the people's representative organs and relevant administrative organs of the higher authorities, etc. However, the judicial relief of public rights should have the highest legal status at the present, which emphasizes the rule of law and the construction of the country under the rule of law.

\title{
Система административного права, предусматривающая участие общественности в принятии административных решений
}

\author{
Гуан Баоинь, Ван Лицюнь \\ (перевод с китайского) \\ Шанхайский университет политики и права \\ Китай, 201701, Шанхай, район Qingpu, \\ Waiqingsong Road, 7989
}

В развитых странах участие общественности в принятии административных решений имеет особый правовой статус в области нормы права, которая путем принятия унифицированных административно-процессуальных законов или специальных законодательных актов обычно регламентирует сферу и права участия общественности. Новые проблемы, с которыми сталкивается Китай в управлении страной в соответствии с законодательством и административным правопорядком, заключаются в выстраивании административной системы права относительно участия общественности в административном принятии решений. Участие общественности в принятии административных решений, как правило, связано с тремя основными вопросами: во-первых, это область административных решений, в которых может участвовать общественность; во-вторых, пути и методы участия общественности в принятии административных решений; в-третьих, административная помощь в участии общественности в принятии административных решений, что требует от нас соответствующей перестройки системы административного права. Мы считаем необходимым построить такие системы, как категория прав административных лии, содержание административных мер, нормы административного решения и административная помощь.

Ключевые слова: участие общественности, административные решения, выстраивание системы.

Научная специиальность: 12.00.00 - юридические науки. 